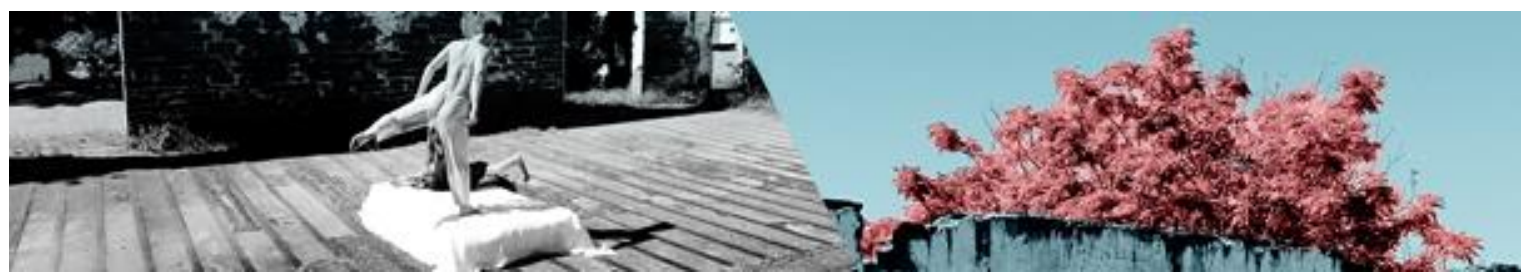

\title{
DO BALÉ CLÁSSICO À DANÇA MODERNA: IMPRESSÕES E PISTAS PARA O ENTENDIMENTO DAS CONCEPÇÕES DE CORPO NA DANÇA
}

Diego Ebling do Nascimento ${ }^{1}$

Resumo: O modelo de corpo estipulado para os bailarinos e bailarinas até o final do século XIX sofre modificações consideráveis com as propostas dos precursores da dança moderna. Este trabalho teórico busca mostrar as transformações referentes às concepções de corpo no período de ruptura entre a dança clássica e a dança moderna, onde a busca por corpos treinados e idênticos se transforma na busca pela liberdade e expressividade corporal. É possível perceber que foi a partir dessas modificações que a dança retoma seu lugar original, criando um espaço-tempo possível de refletir e expor a realidade vivida no momento histórico em que ela acontece.

Palavras-chave: Dança; Corpo; História.

\section{FROM CLASSIC BALLET TO MODERN DANCE: IMPRESSIONS AND TRACKS FOR UNDERSTANDING BODY CONCEPTIONS IN DANCE}

\begin{abstract}
The body model stipulated for dancers until the end of the nineteenth century underwent considerable modifications with the precursors of modern dance. This theoretical work seeks to show the transformations referring to the conception of body in the period of rupture between classical dance and modern dance, in which the search for trained and identical bodies becomes the search for freedom and corporal expressivity. It is possible to perceive that it was from these modifications that the dance resumes its original place, creating a space-time possible to reflect and to expose the lived reality in the historical moment in which it happens.
\end{abstract}

Keywords: Dance; Body; History.

\section{CONSIDERAÇÕES INICIAIS}

Este trabalho é um desdobramento da revisão bibliográfica realizada para a construção da minha dissertação de mestrado intitulada "Macho, bailarino e homossexual: Um olhar sobre as trajetórias de vida de professores dançantes" (NASCIMENTO, 2013). Entretanto, o presente texto tem como objetivo evidenciar as transformações referentes às concepções de corpo no período de ruptura entre a dança clássica e a dança moderna.

Conduzidos pelas ideias de Silva (2008) entendemos que o corpo é resultado da história pessoal e social, do ambiente e, em um contexto maior, da cultura. Este

\footnotetext{
${ }^{1}$ Universidade Federal do Tocantins. Diego Ebling do Nascimento é professor, extensionista e pesquisador na área da dança e da educação física da Universidade Federal do Tocantins. Mestre e licenciado em Educação Física pela Universidade Federal de Pelotas. Especialista em Artes Híbridas e em Dança e Consciência Corporal.
}

NASCIMENTO, Diego Ebling do. Do balé clássico à dança moderna: impressões e pistas para o entendimento das concepções de corpo na dança. Revista da FUNDARTE, Montenegro, p.160-173, ano 19, no 37, Janeiro/Março.

Disponível em: http://.seer.fundarte.rs.gov.br/index.php/RevistadaFundarte/index> 30 de março de 2019. 


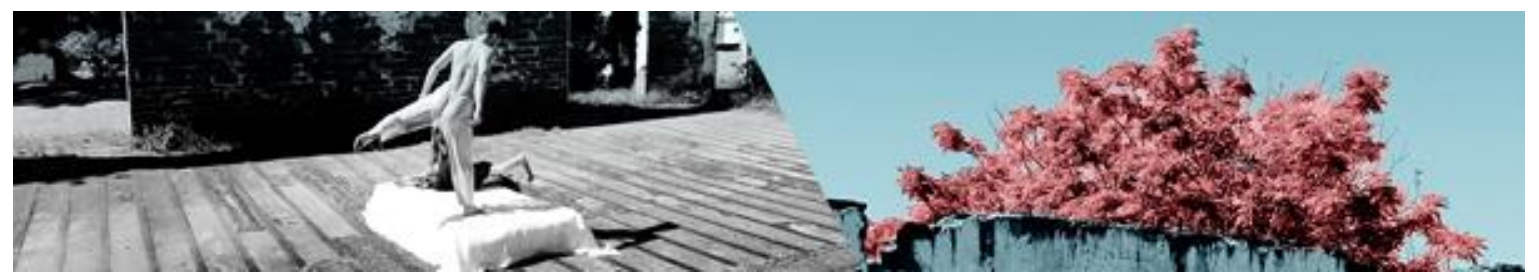

artigo irá tratar das mudanças de concepções de corpo na dança, no período de transição da dança clássica para a dança moderna. De meados do século XVII até o início do século XX outras artes também passaram por modificações consideráveis no que se refere às suas concepções éticas e estéticas do corpo.

$\mathrm{Na}$ arte da dança, o corpo é a matéria prima para realização da composição coreográfica e é por meio do movimento (ou ausência dele) que a dança passa a existir. Siqueira (2006) lembra que o corpo é espaço e reflexo da cultura, lócus de relações sociais (entre quem dança e quem assiste, por exemplo), e quando se movimenta em um espetáculo, obedece, na realidade, a um conjunto de rituais. $\mathrm{Na}$ dança o corpo também sofre alterações por meio de técnicas e tecnologias que pretendem criar novas linguagens para a utilização dos corpos como meio de expressão. Dessa forma, o corpo é intérprete e signo quando participa da dança como espetáculo.

Segundo Amaral (2009, p. 5) "a dança é uma arte criativa e cênica, que tem como objeto, o movimento e, como ferramenta, o corpo. Ela é imanente do corpo; impossível separar a dança do corpo que dança". Logo, entendemos que a dança está diretamente relacionada com o corpo, que, por sua vez, está imerso em uma sociedade que possui valores e crenças. Assim, esses fatores sociais irão influenciar diretamente na construção das danças e dos corpos, provocando movimentos de ordem biológica, estética, social, cultural e ética. Isso possibilita novas formas de se pensar o corpo e a dança, produzindo diferentes estilos, significados e estéticas ao longo da história.

Não é objetivo deste trabalho conceituar "corpo" antropológica ou filosoficamente, e sim focar nos apontamentos e nas evidencias ocorridas sobre o corpo, a partir da ruptura ocorrida na transição da dança clássica para a dança moderna, onde surgiram novas possibilidades de se mover e de ser/estar do corpo ${ }^{2}$ em cena.

\footnotetext{
2 Para um aprofundamento no conceito de "corpo" sugiro a leitura do artigo "Os corpos na sociedade contemporânea" (NASCIMENTO; AFONSO, 2014) publicado na revista Lecturas Educación Física y Deportes (Buenos Aires) onde apresentamos uma discussão voltada à conceitualização do corpo. entendimento das concepções de corpo na dança. Revista da FUNDARTE, Montenegro, p.160-173, ano 19, no 37, Janeiro/Março.

Disponível em: http://.seer.fundarte.rs.gov.br/index.php/RevistadaFundarte/index> 30 de março de 2019.
} 


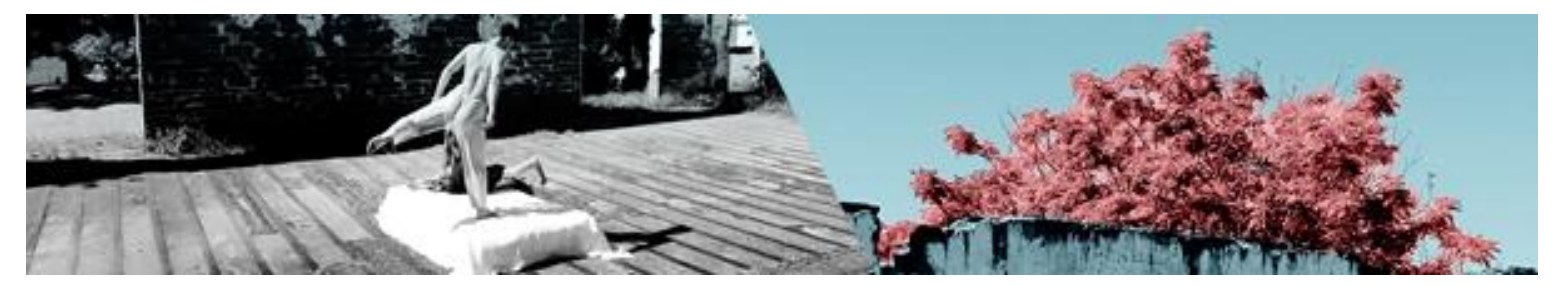

\section{O CORPO NO BALÉ CLÁSSICO}

De acordo com documentos datados no século $\mathrm{XV}$, o balé foi concebido no Renascimento italiano. Posteriormente, foi levado à França e espalhou-se pelo mundo ocidental nos séculos XVII e XVIII (MONTEIRO, 2006). Segundo Dantas (2007), cada estilo de dança se constitui configurando seus modelos de corporeidade dançante, e o balé se tornou, por um longo período, o modelo hegemônico. Os valores oriundos da aristocracia europeia refletiram nas características exigidas para os corpos que dançavam. Como exemplo, podemos ressaltar um dos grandes nomes do balé: a italiana Marie Taglioni (1804-1884). De acordo com Silva (2008, p. 31) Taglioni era "alva, de figura frágil, cabelos negros e mãos expressivas, tornou-se a figura suprema do ideal romântico na dança".

A figura de Taglione representava um modo de ser desejável pela aristocracia. Ser branca e frágil, como cita Silva (2008), são características importantes para refletirmos sobre as obrigações exigidas para a aceitação dos corpos femininos naquele período. Além disso, buscava-se, no balé, um corpo leve, longo e que se projetasse verticalmente, movimentos e características oriundas das cortes francesas e italianas, já altamente codificados. A busca pela leveza acarretou na utilização de sapatilhas especiais, o que tornou Taglioni um marco da dança clássica, pois foi a primeira bailarina a dançar nas pontas dos pés com a utilização de sapatilhas de pontas.

As sapatilhas de pontas são desconfortáveis, visto que devem suportar o peso do corpo em uma base extremamente pequena. Para que isto ocorra, elas levam em sua estrutura uma palmilha rígida e uma gáspea (região onde os dedos são encaixados) (PICON e FRANCHI, 2007). A utilização das sapatilhas de pontas permitia a representação mais fiel de seres fabulosos, extraordinários e excêntricos, como destaca Silva (2008) ao expor que à maioria das obras do período do balé romântico "descrevem estórias fantásticas com personagens como fadas, elfos e cisnes que contracenam com seres reais, como camponeses e príncipes, sempre expressando a dualidade real versus ideal, carnal versus espiritual, vida versus morte" (SILVA, 2008, p. 31). entendimento das concepções de corpo na dança. Revista da FUNDARTE, Montenegro, p.160-173, ano 19, no 37, Janeiro/Março.

Disponível em: http://.seer.fundarte.rs.gov.br/index.php/RevistadaFundarte/index> 30 de março de 2019. 

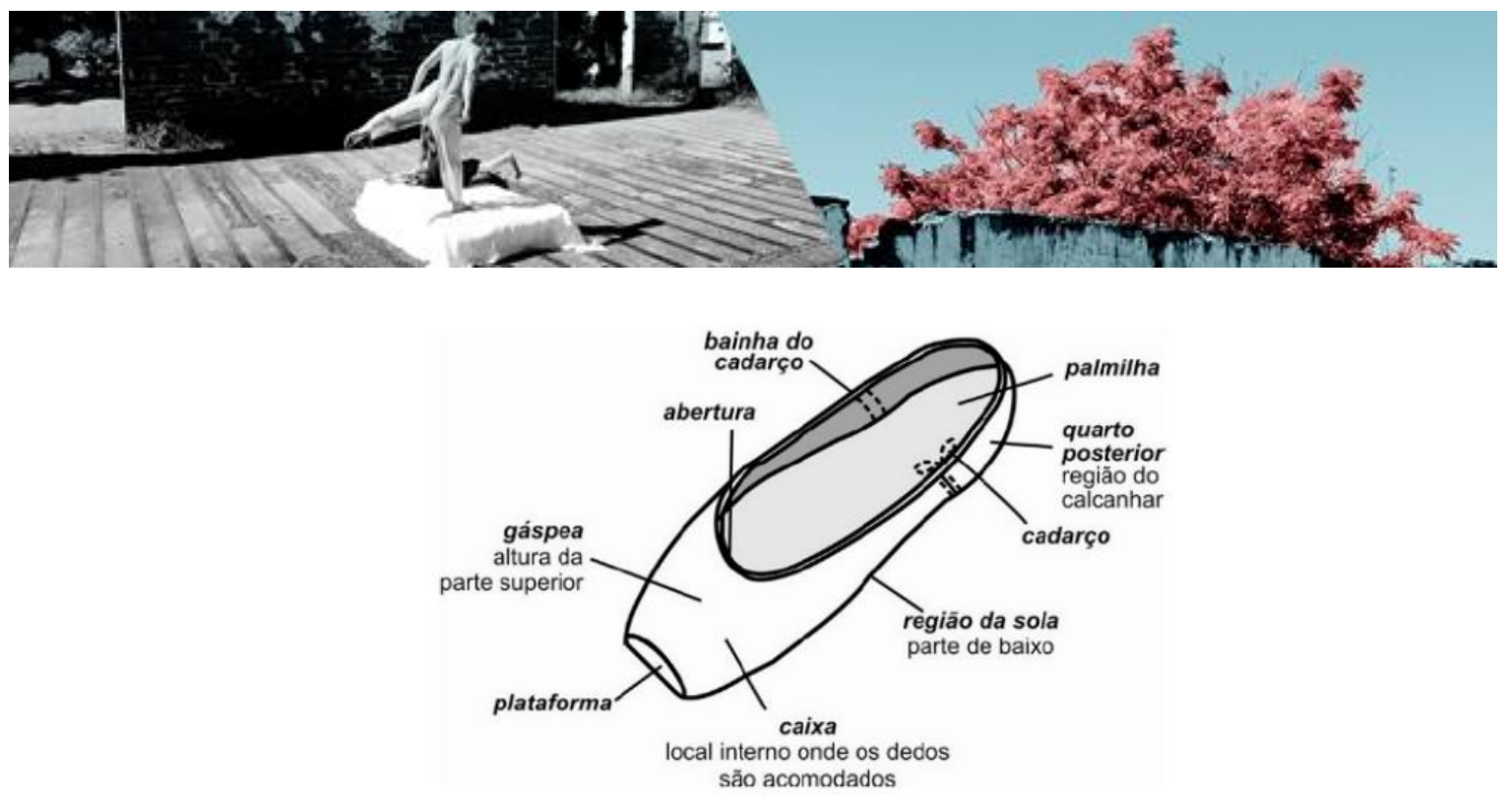

Figura 1 - Partes que compõe a sapatilha de pontas (SANTOS, NAPOLEONE, NOGUEIRA, 2016, p. 1).

Além das sapatilhas de pontas, as mulheres no balé utilizavam espartilhos, 0 que gerava uma limitação nos movimentos das bailarinas, dificultando a movimentação. Tanto o abdômen, quanto a cintura escapular tinham pouca mobilidade, o mínimo para dar alguma expressão, o único movimento que necessitava de uma maior amplitude do tronco era o cambré3 ${ }^{(S A M P A I O, 2014) .}$

Por muitos anos, no ocidente, apenas o balé era visto como dança cênica, e os bailarinos clássicos trabalhavam seus corpos desde muito novos, em busca de uma técnica perfeita que disfarçasse a realização dos esforços que o balé exigia, e se fizesse parecer que os movimentos de seus corpos acontecessem de forma mais natural possível, mas que de fato não eram (BOURCIER, 2001; SAMPAIO, 2014).

No período de desenvolvimento da dança clássica a bailarina precisava ser exaltada, sublime, não tinha um gênero definido, era inatingível e assexuada. Já o bailarino servia apenas como um suporte técnico para potencializar essas características nas bailarinas (SILVA, 2008).

Anjos, Oliveira e Velardi (2015) realizaram uma pesquisa para identificar a construção do corpo ideal no balé clássico da contemporaneidade, e identificaram que o corpo que as bailarinas desejam está na inter-relação de alguns elementos, como a questão física/anatômica (marcada por um corpo magro; longilíneo, flexível; com uma estrutura anatômica que propicie o en dehors ${ }^{4}$ ), um belo colo de pé e,

\footnotetext{
${ }^{3}$ Cabré significa "arqueado. Dobrar o corpo a partir da cintura, para frente, para trás ou para os lados, a cabeça acompanhando o movimento do corpo" (ROSAY, 1980, p. 60).

${ }^{4}$ En dehors é a "rotação externa do fêmur na fossa do acetábulo", ou seja, é "a rotação externa dos quadris, com os joelhos e a ponta dos pés sempre virada para fora" (SAMPAIO, 2001, pp. 47-48).

NASCIMENTO, Diego Ebling do. Do balé clássico à dança moderna: impressões e pistas para o entendimento das concepções de corpo na dança. Revista da FUNDARTE, Montenegro, p.160-173, ano 19, no 37, Janeiro/Março.

Disponível em: http://.seer.fundarte.rs.gov.br/index.php/RevistadaFundarte/index> 30 de março de 2019.
} 


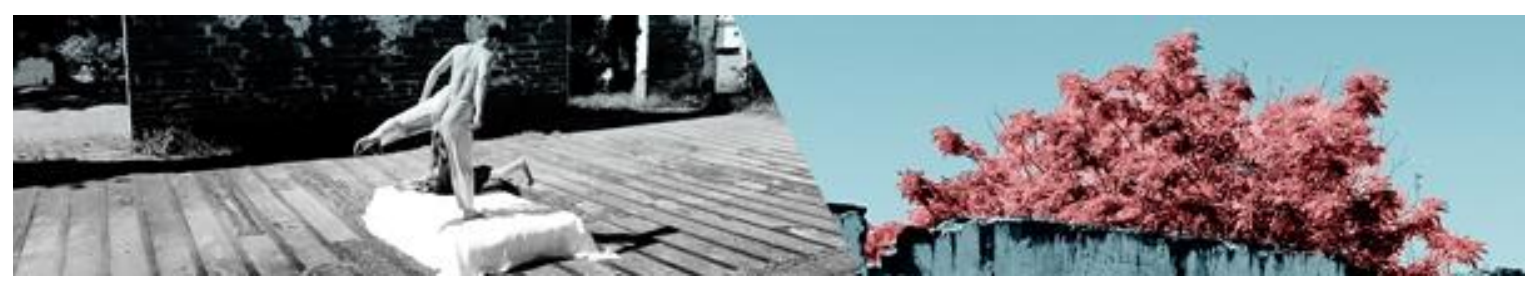

sendo desejável também, uma hiperextensão de membros inferiores, gerando assim uma estética específica das bailarinas. Além disso, as bailarinas têm como referência o corpo determinado pelos grandes nomes do balé na atualidade. Desta forma, a concepção de corpo "segue reconstruindo-se e se reatualizando à medida que os grandes nomes do balé vão mostrando quem e de que maneira selecionam para seus trabalhos. O ideal aqui significa o corpo necessário para se dedicar ao balé clássico" (ANJOS; OLIVEIRA; VELARDI, 2015, p. 449-450).

Outro ponto importante trazido por Anjos, Oliveira e Velardi (2015) é que há uma romantização das bailarinas à dança clássica e esse fator pode levá-las à submissão de regras e especificações exigidas por essa técnica de dança. As autoras salientam que "no caso do balé, a profissão se confunde com paixão - o que também legitima a dedicação extrema das bailarinas e parece justificar sua permanência no balé".

Os padrões de corpo exigidos pela dança clássica, a rigidez da técnica, a busca pelo perfeccionismo, a alta expectativa por parte dos instrutores e familiares e a instabilidade emocional, promovidos pelas pressões exercidas nos corpos pelas pessoas que fazem balé, podem acarretar em torturas corporais e psicológicas em bailarinas e bailarinos até hoje, além de poder promover transtornos alimentares (POLI; SCHEID, 2008).

Em um estudo realizado por Carneiro e Nozaki (2012), de um total de 57 dançarinas participantes da pesquisa, foram identificadas duas adolescentes com comportamento alimentar de risco para Anorexia. Além disso, em relação à autopercepção da imagem corporal em bailarinas, foi realizado um estudo que identificou que "a maioria das bailarinas tem uma preocupação com peso corporal e elevada insatisfação com a própria imagem" (NOGUEIRA, MACEDO e GUEDES, 2010 , p. 550). As autoras também evidenciaram o desejo pela perda de peso das bailarinas, reforçando a preocupação com a aparência física sem a preocupação com os aspectos relacionados à saúde.

Por outro lado, o estudo de Anjos, Oliveira e Velardi (2015) identificou que mesmo com a ideia de que o corpo "perfeito" deve ser magro, as bailarinas apresentam "o discurso da magreza saudável, pois a eficácia da bailarina não pode entendimento das concepções de corpo na dança. Revista da FUNDARTE, Montenegro, p.160-173, ano 19, no 37, Janeiro/Março.

Disponível em: http://.seer.fundarte.rs.gov.br/index.php/RevistadaFundarte/index> 30 de março de 2019. 


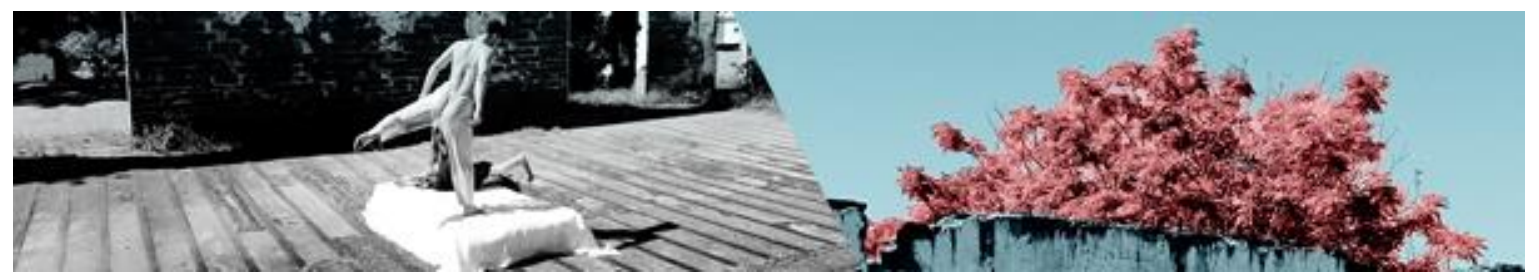

ser comprometida; um corpo funcional para dançar é também essencial". (ANJOS; OLIVEIRA; VELARDI, 2015, p. 450).

No que se refere às questões étnico-raciais na dança clássica, Candiotto (2007) e Ferraz (2017) fazem críticas sobre as consequências do eurocentrismo na dança, embora Ferraz (2017, p 119) explique que "não se trata de alimentar um discurso dicotômico e maniqueísta entre as estéticas afro e euro orientadas", o autor lembra que:

\begin{abstract}
Geralmente as representações sobre as corporalidades negras nas danças das grandes companhias, salvo raras exceções, reproduziram historicamente um olhar exotizante. Os seus sensos rítmicos apurados e gestualidade curvilínea usualmente apareciam filtradas sobre o verniz erudito da "estilização", uma forma de branquear e descaracterizar as estéticas diaspóricas com padronizações que valorassem as estéticas hegemônicas. Ainda hoje a formação clássica aparece reproduzida inquestionavelmente como gramática e forma de treinamento em dança, entendida como essencial para o bom desempenho profissional. No âmbito da formação dos artistas da dança a técnica do balé clássico muitas vezes atuou como modo de higienizar as qualidades e formas de movimento, submetendo o corpo a uma disciplina responsável por afinar os corpos num projeto expressivo eurocentrado. (FERRAZ, 2017, p. 119).
\end{abstract}

Candiotto (2007), embasada nas ideias de Stuart Hall, fez uma reflexão da trajetória de Mercedes Baptista, primeira bailarina clássica negra que entrou para o Teatro Municipal do Rio de Janeiro. A autora evidencia o enfrentamento do preconceito racial de Mercedes. "Em sua jornada, observa-se que é possível identificar que o negro brasileiro carrega uma ferida aberta de um corpo escravizado, discriminado e, por vezes, violentado" (CANDIOTTO, 2007, p. 3).

Os corpos da dança clássica eram e, talvez continuem sendo, expostos ao que Foucault (1977) denominaria por técnica de sujeição, causada pelo aprisionamento dos corpos, seja pelo fato das limitações dos movimentos e incômodos corporais oriundos das vestimentas vinculadas ao balé, pelos passos predefinidos pelos movimentos técnicos ou, ainda, pela demasiada exigência de padrões corporais.

A partir desta colocação, podemos constatar que é nesse contexto de disciplina e controle dos corpos que a dança esteve inserida (e, em alguns casos, ainda está). Assim, apenas resta executar a técnica perfeitamente, obedecendo aos movimentos já estabelecidos por seu mestre. Os sentidos, as memórias, as escolhas entendimento das concepções de corpo na dança. Revista da FUNDARTE, Montenegro, p.160-173, ano 19, no 37, Janeiro/Março.

Disponível em: http://.seer.fundarte.rs.gov.br/index.php/RevistadaFundarte/index> 30 de março de 2019. 


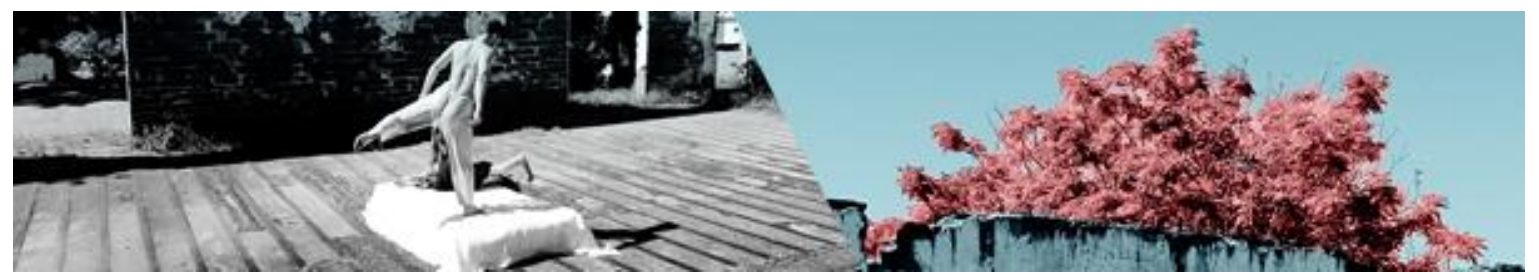

de cada bailarino ficam em segundo plano. Para Mauss (1974, p. 211), a técnica corporal significa "as maneiras como os homens, sociedade por sociedade, e de maneira tradicional, sabem servir-se de seus corpos". O autor diz que a técnica é um ato tradicional eficaz. Sendo assim, não há técnica se não houver tradição. A tradição do balé vem sendo passada de geração para geração há muito tempo, porém, é importante lembrar que o balé não é a única manifestação de dança e nem a única técnica de dança existente.

No entanto, "ainda hoje muitos dançarinos somente são reconhecidos como profissionais tendo comprovado algum conhecimento ou destreza na técnica de dança clássica" (MOREIRA, 2014, p. 89). De acordo com Moreira (2014), alguns estudiosos, observadores e desenvolvedores da dança clássica defendem que os princípios rígidos e objetivos do balé clássico norteiam a dança cênica até os dias de hoje.

\section{AS TRANSFORMAÇÕES DE CONCEPÇÕES FRENTE À DANÇA MODERNA}

A dança moderna surge para romper com o tecnicismo do balé. Isadora Duncan foi uma das pioneiras. Ela não demonstrava interesse pela técnica clássica, utilizava gestos cotidianos como correr, saltar, andar e simplesmente mover os braços para compor seus passos. Buscava reencontrar os movimentos inatos do homem perdidos há anos, "escutar as pulsações da Terra", obedecer à "lei da gravitação". Seu método era respirar naturalmente. Os temas de sua dança eram inspirados na contemplação da natureza, nas ondas, nas nuvens, no vento, nas árvores. Sua arte era ligada às suas emoções pessoais e ela não havia elaborado nem técnica, nem doutrina precisa, mas marcou com brilho o nascimento de uma dança "diferente" (BORCIER, 2001).

Ainda de acordo com Bourcier (2001), Isadora acompanhou cursos de dança acadêmica, mas logo os abandonou, pois recusou o sistema. Ela declarou que queria criar uma dança com seu próprio temperamento. A dança é, para ela, a expressão de sua vida. Busca-se, então, o corpo natural como referência para a elaboração de novas formas coreográficas. Na visão de Dantas (2007) o corpo dançante de Isadora é natural porque respeita a anatomia humana e se constrói em entendimento das concepções de corpo na dança. Revista da FUNDARTE, Montenegro, p.160-173, ano 19, no 37, Janeiro/Março.

Disponível em: http://.seer.fundarte.rs.gov.br/index.php/RevistadaFundarte/index> 30 de março de 2019. 


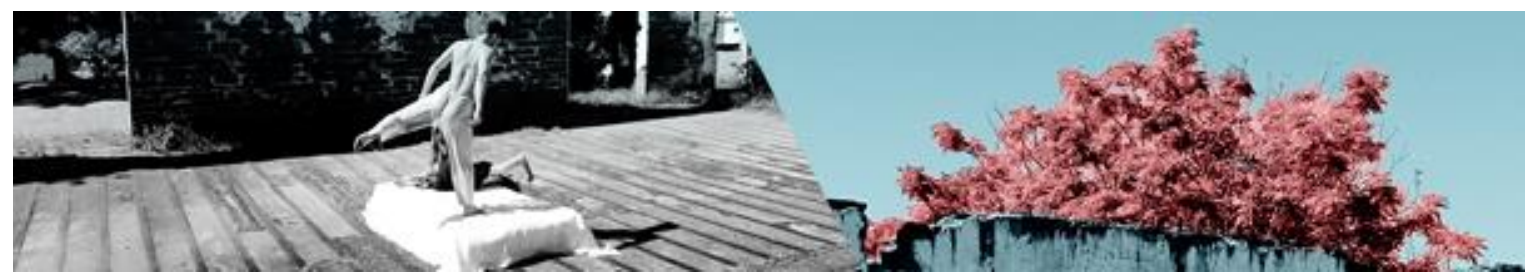

contraponto ao corpo balético, que segundo ela é um corpo artificial, onde o fluxo do movimento é interrompido pela rigidez dos gestos. O problema seria enfrentar a pressão dos padrões sociais que impediriam a livre manifestação de sua arte.

Contudo, Dantas (2007) contrapõe as ideias de Bourcier (2001) relatando que é injusta a crença de que Isadora Duncan não tenha desenvolvido nenhuma técnica. Para a autora, Isadora refletiu intensamente sobre sua arte, estudou o movimento e a espontaneidade. Este fato não deve ser confundido com a ausência de trabalho, tanto físico como intelectual. "Duncan estudou Jean-Jacques Rousseau, Walt Whitman e Nietzsche. Segundo Isadora, ela gostaria de criar uma dança que fosse a expressão divina do espírito humano pelos movimentos do corpo" (DANTAS, 2007, p. 152).

É importante salientar, também, que a dança moderna surge em um momento histórico repleto de mudanças culturais e sociais. A industrialização, a vida urbana e a guerra muito influenciaram para a manifestação estética da dança moderna, pois essas transformações inspiraram a busca por novas formas de fazer dança na Europa e na América (locais do nascimento desta dança).

A 'dança moderna' retoma assim - depois de quatro séculos de 'balé clássico' e vinte séculos de desprezo do corpo por um cristianismo pervertido pelo dualismo platônico - o que foi dança para todos os povos, em todos os tempos: a expressão, através do movimento do corpo organizado em sequências significativas, de experiências que transcendem o poder das palavras e da mímica. (GARAUDY, 1994, p. 13).

As sapatilhas que aprisionavam os pés das bailarinas também foram questionadas por Isadora. Ela se permitiu retirar as sapatilhas e dançar descalça, em contato direto com o chão, com os cabelos soltos e em um palco cru, sem qualquer cenário, pois a sua dança deveria ser a protagonista da cena.

Se formos observar a história mundial, poucas são as mulheres que fazem parte dela. Isso provavelmente se dá pelo fato de as histórias, por muito tempo, serem escritas somente por homens. Contudo, percebemos que na história da dança, nesses dois últimos séculos, abriu-se um espaço para o protagonismo feminino, os nomes de mulheres passaram a ser mais reconhecidos e evidenciados na história. Podemos citar como exemplo, além de Isadora Duncan, outros grandes entendimento das concepções de corpo na dança. Revista da FUNDARTE, Montenegro, p.160-173, ano 19, no 37, Janeiro/Março.

Disponível em: http://.seer.fundarte.rs.gov.br/index.php/RevistadaFundarte/index> 30 de março de 2019. 


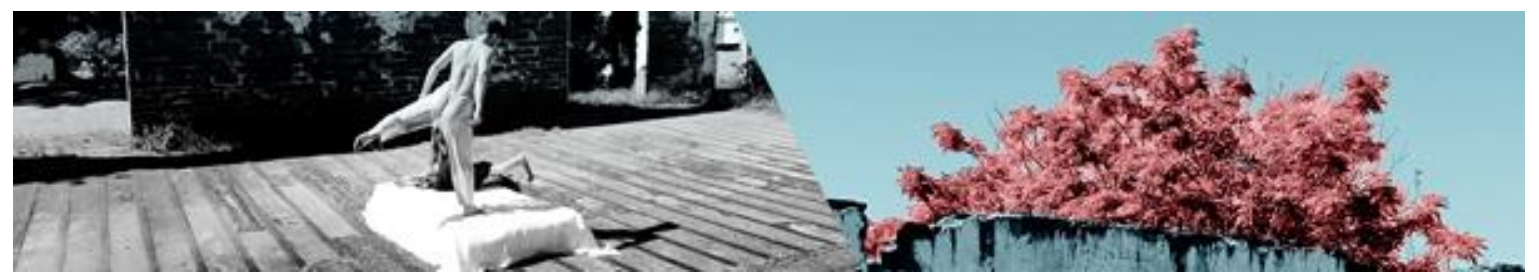

nomes femininos como Doris Humphrey, Ruth San Denis, Loie Fuller, Martha Graham e Mery Wigman que também mudaram, com suas ideias e concepções, o percurso da dança.

Outra mudança significativa da transição do período da dança clássica para a dança moderna foi a abolição dos espartilhos, o que possibilitou a ampliação dos movimentos que antes eram prioritariamente focados nos membros superiores $\mathrm{e}$ inferiores, não havendo grandes possibilidades de mover o tronco. O período da dança moderna possibilitou a substituição dos espartilhos por roupas esvoaçantes confeccionadas com tecidos leves. O tronco, que era aprisionado nas estruturas das roupas, ganhou liberdade de movimentos e passou a ser visto como um potencial para a dança. Os movimentos do centro do corpo começaram a ser estudados e incorporados na construção de novas técnicas e coreografias.

No Brasil, foi também a partir da disseminação da dança moderna e da dança expressionista que o corpo passou a ter lugar para fazer o que desejava. Suzana Maria Coelho Martins ${ }^{5}$, em entrevista feita por Vieira (2009), fala sobre o novo lugar/espaço ocupado pelo corpo na dança: "Temos não mais um corpo produzido pelo lugar, mas um corpo que produz novos lugares e espaços para rupturas. Um corpo que passa a coreografar e dançar sua própria história” (VIEIRA, 2009, p. 9).

A respeito disso, Suzana Martins, em entrevista dada a Vieira (2009), colabora com falas sobre as contribuições da dança moderna no Brasil.

\begin{abstract}
Até então, não se trabalhava a liberdade dos movimentos espontâneos do corpo humano, nem temas que falassem das condições humanas, nem as ações naturais como respiração, a força de gravidade, a transferência do peso do corpo e a integração do corpo físico com o intelecto e o espírito, nem a alternativa de se dançar descalços ou com sapatilhas fabricadas de material leve; tudo isso foi implementado mediante o advento das danças Moderna e Expressionista. (VIEIRA, 2009, p. 16).
\end{abstract}

Segundo Vieira (2009), a dança moderna possibilitou tratar o corpo como lócus privilegiado de crítica à sociedade contemporânea. Inspirada em Foucault a autora coloca que

\footnotetext{
${ }^{5}$ Dançarina, professora e pesquisadora em Dança, graduada em Licenciatura em Dança (1973) pela Escola de Dança da Universidade Federal da Bahia, Mestrado (1980) e Doutorado (1995) pela Temple University (EUA) e Pós-Doutorado (2005) pela CODARTS (Roterdã, Holanda).

NASCIMENTO, Diego Ebling do. Do balé clássico à dança moderna: impressões e pistas para o entendimento das concepções de corpo na dança. Revista da FUNDARTE, Montenegro, p.160-173, ano 19, no 37, Janeiro/Março.

Disponível em: http://.seer.fundarte.rs.gov.br/index.php/RevistadaFundarte/index> 30 de março de 2019.
} 


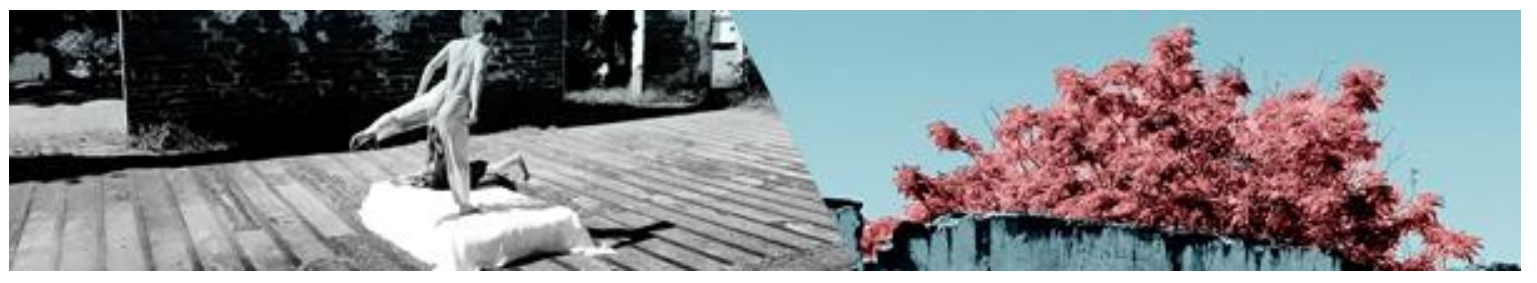

[...] as novas perspectivas de corpo (...) podem ser tratadas a partir da ideia de corpo reconstrução: é no corpo e por meio dele que são forjadas as sujeições, mas, também, que se abrem espaços de subversão. Pelas novas propostas de dança se inventam corpos, se resiste ao poder, se desestabilizam as representações e discursos tradicionais acerca da sexualidade e de gênero, e se geram desvios microscópicos que abalam o pensamento. (VIEIRA, 2009, p. 16).

Contudo, Tomazzoni (2004) diz que, mesmo com a ruptura ocorrente, ainda se percebem os entraves históricos constituídos no balé e que foram refletidos na dança moderna. O autor salienta que mesmo que os pioneiros e criadores da dança moderna tenham trazido maior liberdade para o uso do corpo na criação em dança, as técnicas como de Martha Graham, Merce Cunningham, José Limon, entre outros, ainda se pautavam pela perspectiva na qual o corpo cotidiano não encontrava lugar no espaço. Além disso, "as conotações eróticas mais explícitas eram suprimidas das criações. A dança continuava, então, sem expressar abertamente a sexualidade, até que os movimentos feministas e gays a liberassem de seus ideais andróginos" (SILVA, 2008, p. 33).

\section{CONSIDERAÇÕES FINAIS}

Ao chegarmos ao final do texto é importante retomarmos as contribuições dos precursores e criadores da dança moderna para as modificações ocorridas referentes às formas de ver, conceber e apresentar o corpo na dança. Os únicos corpos possíveis para a dança deveriam ser obedientes e treinados e passam a poder ser livres e espontâneos. A realidade política, econômica, religiosa e social se tornaram temas importantes e presentes nas obras de dança na modernidade, sendo isso o reflexo das transformações propostas pelos precursores e criadores da dança moderna.

A libertação dos espartilhos, a utilização de tecidos mais leves para a dança e a possibilidade de se dançar descalço foram pontos importantes nessa ruptura. Além disso, a respiração, a transferência do peso do corpo e a força da gravidade também passaram a fazer parte dos corpos que dançam. É possível perceber que foi a partir dessas modificações que a dança retoma seu lugar original, criando um espaço- 


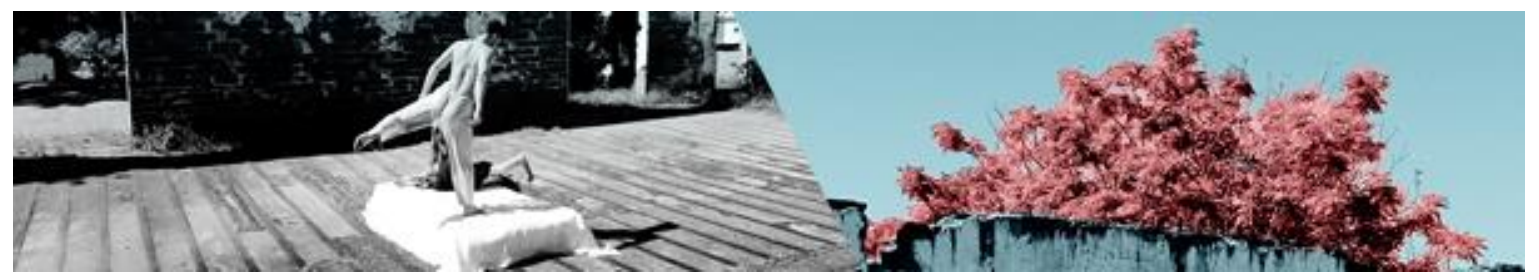

tempo possível de refletir e expor a realidade vivida no momento histórico em que ela acontece.

Foram inúmeras as contribuições da dança moderna para as rupturas referentes ao ideal de corpo construídas pelo balé clássico. No entanto, as alternativas de libertação trazidas pela dança moderna ainda deixavam o cotidiano de fora. Este fato só seria revisto de forma mais eficaz pela dança pós-moderna americana, na década de 60, em Nova lorque. Coreógrafos como Trisha Brown e Steven Paxton passam a usar corpos e movimentos cotidianos. Deste modo, não bailarinos também podiam estar em cena fazendo dança (TOMAZZONI, 2004).

$\mathrm{Na}$ pós-modernidade, a dança não se interessa mais em apresentar corpos perfeitos, unificados pela forma e delineados por padrões estéticos ou sexuais. Tudo passa a ser permitido. "A dança parece querer, de fato, expressar a multiplicidade corporal feita de músculos, ossos, nudez, imperfeições e qualidades do ser humano, falando de si próprios, para uma plateia que se identifique com o que vê" (SILVA, 2008, p. 33).

Segundo Tomazzoni (2004) as questões referentes à escolha por corpos cotidianos não se tratam apenas de uma postura estética, mas também de uma postura ética com o corpo e com a dança. Ao se referir à dança na atualidade o autor salienta que "[...] por mais que a tradição, o elitismo e o corporativismo reneguem, a arte da dança revela que não está restrita a alguns eleitos, e que não existe um padrão ou modelo de corpo apenas autorizado a dançar" (TOMAZZONI, 2004, p. 53).

Nesse mesmo sentido, Katz (2004) destaca que, na dança contemporânea, o que passa a ser necessário não é mais somente a carne e os ossos do corpo das bailarinas e dos bailarinos em cena, mas também conseguir identificar como e/ou para que o corpo faz o que faz.

O que muda, basicamente, é o velho entendimento tácito de que o critério para distinguir a dança contemporânea repousa na compreensão de que ela decorre como efeito exclusivo do treinamento do corpo. Mais ou menos como se as marcas de uma técnica condicionassem também as suas possibilidades composicionais, cabendo ao corpo cumprir uma relação determinista entre técnica e estética da qual não pode escapar. Se isto não ocorre, apesar da técnica inscrever marcas que dirigem o desempenho do corpo, significa que os passos, os gestos, as sequências, as frases, que entendimento das concepções de corpo na dança. Revista da FUNDARTE, Montenegro, p.160-173, ano 19, no 37, Janeiro/Março.

Disponível em: http://.seer.fundarte.rs.gov.br/index.php/RevistadaFundarte/index> 30 de março de 2019. 


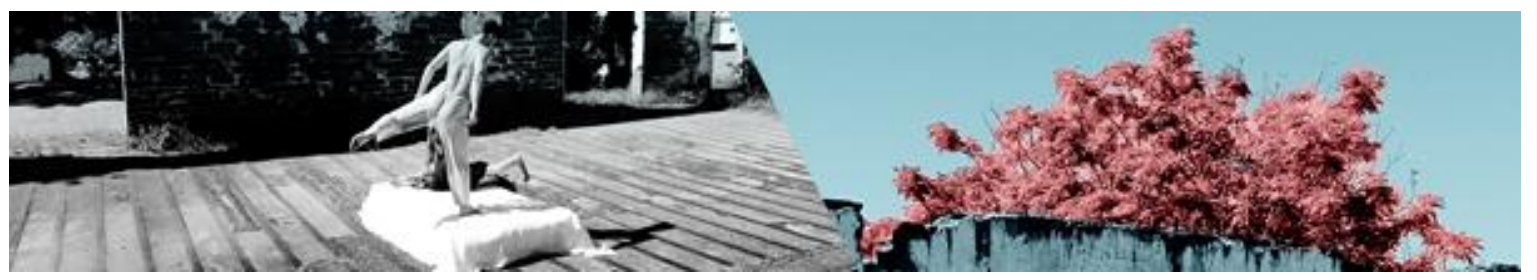

tudo isso pode ser montado, remontado e desmontado de modos sempre novos, desmanchando aquelas expectativas que o hábito automatizou em nós. (KATZ, 2004. p. 1-2).

Ainda hoje, no entanto, mesmo com todas essas modificações e resistências ao longo da história da dança, presenciamos a busca contínua pela normatização dos corpos para a dança em determinadas instituições. Corpos esses que devem estar sempre em busca do modelo estético hegemônico da dança, e que, se por ventura, afastarem-se dos padrões, correm 0 risco de serem ridicularizados, humilhados e até mesmo expulsos por colegas, diretores e coreógrafos dos seus espaços de atuação.

Para concluir, assim como Tomazzoni (2004), compreendemos que as escolhas estéticas na cena são também escolhas éticas, e coreógrafos e diretores deveriam ter a lucidez de aproveitar a riqueza da diversidade e levar para suas obras as multiplicidades de corpos presentes na contemporaneidade. Diante disso, deixamos algumas perguntas para os leitores que embarcaram conosco na reconstrução histórica das concepções de corpo na dança: será que algum dia iremos superar, por completo, as amarras e os preconceitos estabelecidos há séculos sobre os corpos de bailarinas e bailarinos? Qual é o futuro dos corpos na cena da dança? Como você enquanto professor, pesquisador, artista ou até mesmo espectador pode contribuir para ampliar o olhar sobre os corpos que dançam?

\section{Referências:}

AMARAL, Jaime. Das danças rituais ao ballet clássico. Revista Ensaio Geral, v. 1, n. $1,2009$.

ANJOS, Kátia Silva Souza dos; OLIVEIRA, Régia Cristina; VELARDI, Marília. A construção do corpo ideal no balé clássico: uma investigação fenomenológica. Revista Brasileira de Educação Física e Esporte, v. 29, n. 3, p. 439452, 2015.

BOURCIER, Paul. História da Dança no Ocidente. $2^{\circ}$ Edição - São Paulo: Martins Fontes, 2001.

CANDIOTTO, Viviane Maria. Da Diáspora de Stuart Hall para Dança de Mercedes Baptista. II Seminário de Educação, Conhecimento e Processos Educativos: entendimento das concepções de corpo na dança. Revista da FUNDARTE, Montenegro, p.160-173, ano 19, no 37, Janeiro/Março.

Disponível em: http://.seer.fundarte.rs.gov.br/index.php/RevistadaFundarte/index> 30 de março de 2019. 


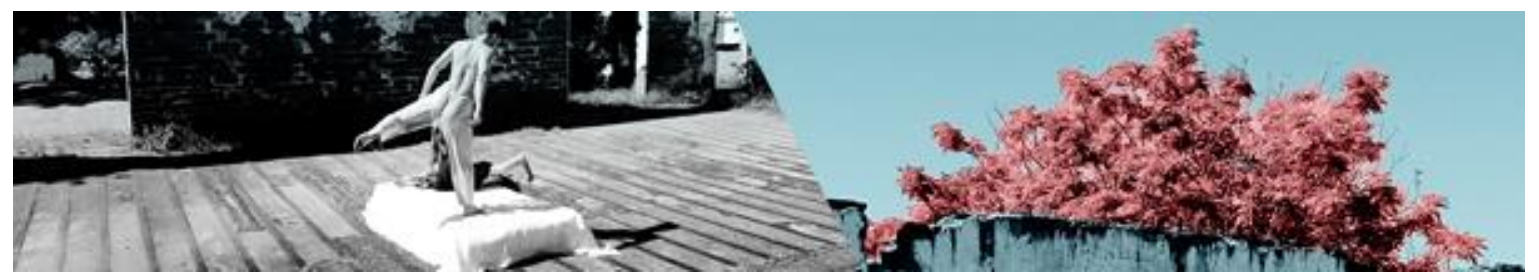

Educação, Arte e Direitos Humanos - Educação, Linguagem e Memória, Universidade do Extremo Sul Catarinense, SC, 2007.

CARNEIRO, Ronilze Almeida; NOZAKI, Vanessa Taís. Ocorrência de anorexia e bulimia nervosa em bailarinas na cidade de dourados-MS. Saúde e Pesquisa, v. 5, n. 3, 2012.

DANTAS, Mônica. O corpo natural de Isadora Duncan e o natural do corpo em educação somática: apontamentos para uma história do "corpo natural" em dança. In: GOELLNER, Silvana Vilodre; JAEGER, Angelita Alice (org.). Garimpando Memórias: Esporte, Educação Física, Lazer e Dança. Porto Alegre - Editora da UFRGS, 2007.

FERRAZ, Fernando Marques Camargo. Danças Negras: Entre Apagamentos e Afirmação no Cenário Político das Artes. Revista Eixo, v. 6, n. 2, p. 115-124, 2017.

FOUCAULT, Michel. Vigiar e Punir: história da violência nas prisões. Editora Vozes. Petrópolis, 1977.

GARAUDY, Roger. Dançar a vida. 6ª edição - Rio de Janeiro: Nova Fronteira, 1994.

KATZ, Helena. O corpo como mídia de seu tempo: a pergunta que o corpo faz. Cd Rom, Rumos Itaú Cultural - Dança. Itaú Cultural, São Paulo, 2004.

MAUSS, Marcel. Sociologia e Antropologia. V.2 Editora Pedagógica e Universitária Ltda e Editora da Universidade de São Paulo. São Paulo, 1974.

MONTEIRO, M. Noverre. Cartas sobre dança. São Paulo: Edusp-FAPESP, 2006.

MOREIRA, Rui. Balé clássico: um dos métodos de formação e preparo de artistas de dança expressiva cênica na contemporaneidade. A Dança Clássica: dobras e extensões. Organização: Instituto Festival de dança de Joinville - Joinville: Nova Letra, 2014.

NASCIMENTO, Diego Ebling. Macho, bailarino e homossexual: Um olhar sobre as trajetórias de vida de professores dançantes. Pelotas, 2013. Dissertação (Mestrado em Educação Física) - Programa de Pós-Graduação em Educação Física, Escola Superior de Educação Física, Universidade Federal de Pelotas, Pelotas, 2013.

; AFONSO, M. R. Os corpos na sociedade contemporânea. Lecturas Educación Física y Deportes (Buenos Aires), v. ano 18, p. 1-3, 2014.

NOGUEIRA, Simone Gomes; MACEDO, Viviane Silva; GUEDES, Patrícia Mendes. Avaliação da imagem corporal e de comportamentos alimentares como possíveis desencadeadores de transtornos alimentares em bailarinas pré-adolescentes. Revista Nutrir Gerais, Ipatinga, v. 4, n. 6, p. 538-553, fev./jul. 2010.

PICON, Andreja Paley; FRANCHI, Silmara Spinardi. Análise antropométrica dos pés de praticantes de ballet clássico que utilizam sapatilhas de ponta. Revista Brasileira Multidisciplinar, v. 11, n. 1, p. 177-188, 2007. entendimento das concepções de corpo na dança. Revista da FUNDARTE, Montenegro, p.160-173, ano 19, no 37, Janeiro/Março.

Disponível em: http://.seer.fundarte.rs.gov.br/index.php/RevistadaFundarte/index> 30 de março de 2019. 


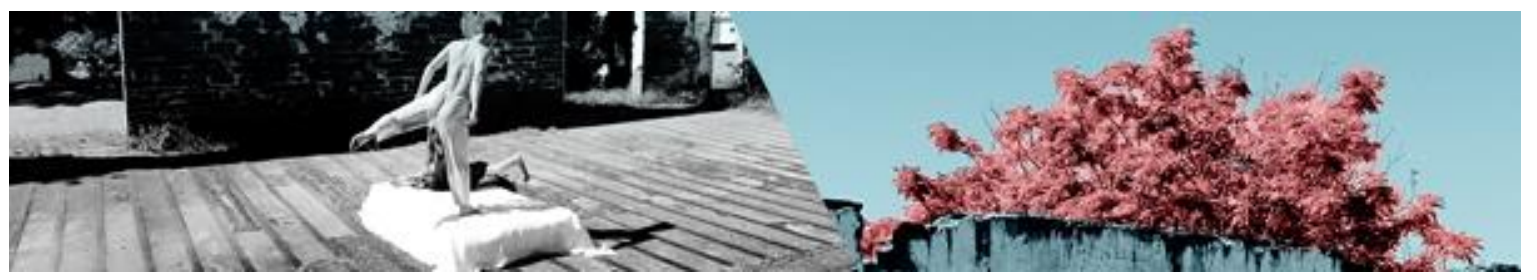

POLI, Caroline Zavarize; SCHEID, Marlene Maria Amaral. Comportamento alimentar e percepção corporal de bailarinas. XII Encontro Latino Americano de Iniciação Científica e VIII Encontro Latino Americano de Pós-Graduação - Universidade do Vale do Paraíba, 2008.

ROSAY, Madeleine. Dicionário de Ballet. 6ª ed. Rio de Janeiro: Nórdica, 1980.

SAMPAIO, Flávio. Ballet essencial. $3^{\underline{a}}$ ed. Sprint, 2001.

Balé: processos - a estabilidade e a perpendicularidade. In: A Dança Clássica: dobras e extensões. Organização: Instituto Festival de dança de Joinville Joinville: Nova Letra, 2014.

SANTOS, C. P. S.; NAPOLEONE, F.M.G.G.; NOGUEIRA, D. V. Análise antropométrica do pé e sua relação com a força de flexão plantar em bailarinas. In: XX Encontro Latino Americano de Iniciação Científica, XVI Encontro Latino Americano de Pós-Graduação e VI Encontro de Iniciação à Docência - Universidade do Vale do Paraíba, 2016.

SILVA, Eliana Rodrigues. As configurações do corpo na cena artística contemporânea. Cogito, v. 9, p. 29-34, 2008.

SIQUEIRA, Denise Costa Oliveira. Corpo, comunicação e cultura: a dança contemporânea em cena. Campinas - São Paulo: Autores Associados, 2006.

TOMAZZONI, Airton. O cotidiano na criação em dança: explicitações ainda necessárias. Revista da Fundarte, ano IV, vol. IV, n 8, jul/dez, 2004.

VIEIRA, Alba Pedreira. Dançando nos espaços de ruptura: olhares sobre influências das danças modernas e expressionistas no Brasil. Fênix, Revista de História e Estudos Culturais. Vol. 6, ano VI, no 3, 2009. Disponível em: $<$ http://www.revistafenix.pro.br/PDF20/ARTIGO 9 Alba Pedreira Vieira FENIX JU L AGO SET 2009.pdf> Acessado em: 06 de março de 2018. entendimento das concepções de corpo na dança. Revista da FUNDARTE, Montenegro, p.160-173, ano 19, no 37, Janeiro/Março. 